\title{
Burkholderia kururiensis sp. nov., a trichloroethylene (TCE)-degrading bacterium isolated from an aquifer polluted with TCE
}

\author{
Hui Zhang, ${ }^{1}$ Satoshi Hanada, ${ }^{1}$ Toru Shigematsu, ${ }^{1}$ Katsutoshi Shibuya, ${ }^{2}$ \\ Yoichi Kamagata, ${ }^{1}$ Takahiro Kanagawa ${ }^{1}$ and Ryuichiro Kurane ${ }^{1}$
}

\footnotetext{
1 National Institute of Bioscience and Human Technology, Agency of Industrial Science and Technology, 1-1 Higashi, Tsukuba 305-8566, Japan

2 Institute of Technology, Shimizu Co., 4-17 Etchujima 3-chome, Koto-ku, Tokyo 135-8530 Japan
}

\author{
Author for correspondence: Yoichi Kamagata. Tel: +81 29864 6591. Fax: +81 298546587 \\ e-mail: kamagata@nibh.go.jp
}

\begin{abstract}
A trichloroethylene (TCE)-degrading bacterium was isolated from an aquifer sample collected at a TCE-polluted site in Japan by enriching with phenol as sole carbon source. The isolate, designated strain $\mathrm{KP23}^{\top}$, was a Gram-negative, oval-shaped micro-organism. A phylogenetic study based on 16S rRNA gene sequences indicated that strain $\mathrm{KP}^{2} 3^{\top}$ should be placed in the genus Burkholderia. Cellular fatty acids of the strain were mainly composed of $C_{16: 0}$ cyclopropanic acid $\mathrm{C}_{17: 0}$ and cyclopropanic acid $\mathrm{C}_{19: 0^{\circ}}$. Strain $\mathrm{KP23}^{\top}$ also contained notable amounts of $C_{13: 1}$ and $C_{17: 1}$. The $G+C$ content of total DNA was $64.8 \mathrm{~mol} \%$. Strain KP23 ${ }^{\top}$ oxidized various sugars and sugar alcohols as sole carbon source such as galactose, glucose, mannose, maltose, glycerol, inositol and mannitol. Comparisons of its phenotypic and genotypic characteristics with other known species belonging to the genus Burkholderia suggested that strain KP23 ${ }^{\top}$ represents a new species in the genus. The name Burkholderia kururiensis is proposed for this species, with strain $\mathrm{KP}^{2} 3^{\mathrm{T}}$ as the type strain (= JCM 10599').
\end{abstract}

Keywords: trichloroethylene degradation, Burkholderia kururiensis sp. nov., aquifer, 16S rRNA gene

\section{INTRODUCTION}

Trichloroethylene (TCE) has been used as a solvent in manufacturing to clean grease from machinery all over the world. Like many other chlorinated hydrocarbons, it has become one of the most abundant environmental pollutants because of its toxic properties and widespread occurrence in soil and groundwater in many countries. TCE removal by dumping or air stripping is restricted by legislation and thus attention is now being paid to biological degradation in soil and groundwater. In the past decade, research on the application of bacteria to the aerobic biodegradation of TCE has progressed and a wide variety of microorganisms has been investigated for this purpose. Most of these bacteria belong to the Proteobacteria such as Methylococcus capsulatus (Stainthorpe et al., 1990),

Abbreviations: FAME, fatty acid methyl ester; TCE, trichloroethylene; UQ, ubiquinone.

The GenBank/EMBL/DDBJ accession number for the 165 rRNA gene sequence of strain $K P 23^{\top}$ is $A B 024310$.
Methylosinus trichosporium OB3b (Cardy et al., 1991), Methylocystis sp. strain M (McDonald et al., 1997), Pseudomonas sp. strain CF600 (Nordlund et al., 1990), Pseudomonas putida strain H (Herrmann et al., 1995), Pseudomonas putida F1 (Wackett \& Householder, 1989), Pseudomonas mendocina (Yen et al., 1991), Burkholderia cepacia G4 (Shields et al., 1989), Ralstonia pickettii (objective synonym of Pseudomonas pickettii) (Byrne et al., 1995) and Ralstonia eutropha (objective synonym of Alcaligenes eutrophus) (Kim et al., 1996).

In these organisms, TCE degradation is catalysed by monoxygenases or dioxygenases which are induced by specific substrates relevant to the enzymes. The inducers include various aromatic and aliphatic hydrocarbons such as toluene (Nelson et al., 1987, 1988), phenol (Folsom et al., 1990; Harker \& Kim, 1990), isopropylbenzene (Dabrock et al., 1992), propane (Wackett et al., 1989) and methane (Little et al., 1988; Tsein et al., 1989).

Recently, we isolated a novel TCE-degrading bacterium, designated strain $\mathrm{KP} 23^{\mathrm{T}}$, from a site polluted 
with this contaminant. The isolate was capable of substantial phenol degradation and TCE appeared to be co-metabolized with phenol. Phylogenetic analysis based on 16S rRNA gene sequences indicated that strain KP23 $3^{\mathrm{T}}$ belongs to the genus Burkholderia and that the strain is distant enough from any other known species in the genus to be classified as a new species.

In this paper, we detail the phenotypic and genotypic features of the isolate which distinguish it from authentic species in the genus Burkholderia and propose a new name for it, Burkholderia kururiensis sp. nov.

\section{METHODS}

Isolation and growth conditions. Strain $\mathrm{KP} 23^{\mathrm{T}}$ was isolated from an aquifer sample collected from a TCE-polluted site in Kururi, Chiba Prefecture, Japan (March, 1996). The geological and environmental properties of the aquifer were detailed by Hanada et al. (1998). The concentration of dissolved oxygen in the ground water was approximately $8 \mathrm{mg} \mathrm{l}^{-1}$. The $\mathrm{pH}$ and temperature of the groundwater were $6 \cdot 7$ and $15-16^{\circ} \mathrm{C}$, respectively.

For enrichment from the environmental samples, BSM medium supplemented with phenol at a final concentration of $2 \mathrm{mM}$ was used. The BSM medium ( $\mathrm{pH} \mathrm{7.0)} \mathrm{contained} \mathrm{the}$ following components $\left(1^{-1}\right): \mathrm{K}_{2} \mathrm{HPO}_{4}, 1 \cdot 0 \mathrm{~g} ; \mathrm{MgSO}_{4} .7 \mathrm{H}_{2} \mathrm{O}$, $0 \cdot 2 \mathrm{~g} ; \mathrm{NaCl}, 0 \cdot 1 \mathrm{~g} ; \mathrm{CaCl}_{2} . \mathrm{H}_{2} \mathrm{O}, 0 \cdot 1 \mathrm{~g} ;\left(\mathrm{NH}_{4}\right)_{2} \mathrm{SO}_{4}, 1 \cdot 0 \mathrm{~g}$; and $\mathrm{FeCl}_{3}, 0.02 \mathrm{~g}$. The enrichment was shaken vigorously at $30{ }^{\circ} \mathrm{C}$. LB (Luria-Bertani) medium supplemented with $1.5 \%$ agar was used for isolation. PE medium (Hanada et al., 1995) was used for physiological and morphological analyses of the isolate. The PE medium contained the following components $\left(1^{-1}\right)$ : sodium glutamate, $0.5 \mathrm{~g}$; sodium succinate, $0.5 \mathrm{~g}$; sodium acetate, $0.5 \mathrm{~g}$; $\left(\mathrm{NH}_{4}\right)_{2} \mathrm{SO}_{4}, 0.5 \mathrm{~g}$; yeast extract (Difco), 0.5 g; Casamino acids (Difco), 0.5 g; $\mathrm{KH}_{2} \mathrm{PO}_{4}, 0.38 \mathrm{~g} ; \mathrm{K}_{2} \mathrm{HPO}_{4}, 0.39 \mathrm{~g}$; vitamin mixture, $1 \mathrm{ml}$; and a basal salt solution, $5 \mathrm{ml}$. The vitamin mixture contained (per $100 \mathrm{ml}$ ) nicotinic acid, $100 \mathrm{mg}$; thiamin hydrochloride, $100 \mathrm{mg}$; biotin, $5 \mathrm{mg}$; $p$-aminobenzoic acid, $50 \mathrm{mg}$; vitamin $\mathrm{B}_{12}, 1 \mathrm{mg}$; calcium pantothenate, $50 \mathrm{mg}$; pyridoxine hydrochloride, $50 \mathrm{mg}$; and folic acid, $50 \mathrm{mg}$. The basal salt solution contained $\left(1^{-1}\right) \mathrm{FeSO}_{4} \cdot 7 \mathrm{H}_{2} \mathrm{O}$, $1.11 \mathrm{~g} ; \quad \mathrm{MgSO}_{4} .7 \mathrm{H}_{2} \mathrm{O}, \quad 24.65 \mathrm{~g} ; \mathrm{CaCl}_{2} .2 \mathrm{H}_{2} \mathrm{O}, 2.94 \mathrm{~g}$; $\mathrm{NaCl}, 23.4 \mathrm{~g} ; \mathrm{MnSO}_{4} \cdot 4 \mathrm{H}_{2} \mathrm{O}, 111 \mathrm{mg} ; \mathrm{ZnSO}_{4} .7 \mathrm{H}_{2} \mathrm{O}$, $28.8 \mathrm{mg} ; \mathrm{Co}\left(\mathrm{NO}_{3}\right)_{2} \cdot 6 \mathrm{H}_{2} \mathrm{O}, 29 \cdot 2 \mathrm{mg} ; \mathrm{CuSO}_{4} .5 \mathrm{H}_{2} \mathrm{O}, 25 \cdot 2 \mathrm{mg}$; $\mathrm{Na}_{2} \mathrm{MoO}_{4} .2 \mathrm{H}_{2} \mathrm{O}, 24.2 \mathrm{mg} ; \mathrm{H}_{3} \mathrm{BO}_{4}, 31.0 \mathrm{mg}$; and trisodium EDTA, $4.53 \mathrm{~g}$. A simplified PE medium containing $\left(1^{-1}\right)$ $\left(\mathrm{NH}_{4}\right)_{2} \mathrm{SO}_{4}, 0.5 \mathrm{~g} ; \mathrm{KH}_{2} \mathrm{PO}_{4}, 0.38 \mathrm{~g} ; \mathrm{K}_{2} \mathrm{HPO}_{4}, 0.39 \mathrm{~g}$; and basal salt solution, $5 \mathrm{ml}$ was used for testing aromatic substrate utilization. The $\mathrm{pH}$ of the media was adjusted to $7 \cdot 2$ with $\mathrm{NaOH}$. Liquid cultures of strain $\mathrm{KP} 23^{\mathrm{T}}$ were incubated at $37^{\circ} \mathrm{C}$ with vigorous agitation.

Morphology. Gram staining was performed as described by Magee et al. (1975). Cell morphology was observed with a phase-contrast microscope (Olympus AX80T). For electron microscopy of ultra-thin sections, cells were embedded in Spurr medium (Kushida, 1980) after fixing with $2.5 \%$ (v/v) glutaraldehyde and $1 \%(\mathrm{v} / \mathrm{v})$ osmium tetroxide. Photomicrographs of the sections were obtained with a Hitachi $\mathrm{H}-$ 7000 transmission electron microscope operated at $75 \mathrm{kV}$.

Quinone analysis. Quinones were extracted with chloroformmethanol $(2: 1, \mathrm{v} / \mathrm{v})$. The extract was purified with a Sep-Pak
Plus column (Waters) and analysed by reverse-phase HPLC (Beckman System Gold with a Hewlett Packard Zorbox ODS column) for identification (Tamaoka et al., 1983).

Physiological and biochemical characterization. TCE degradation was determined using the method described by Hanada et al. (1998). TCE degradation was assumed to follow pseudo-first-order kinetics with respect to substrate. The pseudo-first-order degradation rate constant $k_{1}\left(1 \mathrm{~g}^{-1}\right.$ $\mathrm{h}^{-1}$ ) was measured as described by Speitel et al. (1993).

Oxidase activity was determined by monitoring the oxidation of tetramethyl- $p$-phenylenediamine on a filter paper, and catalase activity was determined by adding cells to a $3 \%$ hydrogen peroxide solution (Smibert \& Krieg, 1994). Gelatin liquefaction was tested at $25^{\circ} \mathrm{C}$ by the method described by Yabuuchi et al. (1992). Carbon source oxidation was determined with a BIOLOG GN system. Results were read automatically with a spectrophotometer after 7 and $24 \mathrm{~h}$ incubation at $37^{\circ} \mathrm{C}$. All tests were run in triplicate. Aromatic substrate utilization was tested by supplementing aromatic substrates to the simplified PE medium at a final concentration of $2 \mathrm{mM}$.

Fatty acid methyl ester (FAME) analysis. FAME analysis, which is based on the conversion of fatty acids to methyl esters by mild acidic methanolysis, followed by gas chromatography analysis, was performed at the Microbial Analysis Laboratory of Microcheck Inc. (Northfield, USA) using the methods described by Welch (1991) and Sasser \& Wichman (1991).

DNA base composition. Total DNA of strain KP $23^{\mathrm{T}}$ was extracted according to the procedure of Saito \& Miura (1963). It was digested with P1 nuclease using a Yamasa GC kit (Yamasa Shoyu). The $\mathrm{G}+\mathrm{C}$ content was measured by HPLC (Kamagata \& Mikami, 1991).

$16 S$ rRNA gene sequence and phylogenetic analysis. For determination of the 16S rRNA gene (rDNA) sequence of strain $\mathrm{KP} 23^{\mathrm{T}}$, cells were lysed by the method of Hiraishi (1992). The 16S rDNA fragment was amplified by PCR (Hiraishi et al., 1994) using the universal primers forward: 5'-AGAGTTTGATCATGGCTCGA-3' (positions 8-27 of the Escherichia coli 16S rRNA gene) and reverse: 5'GGCTACCTTGTTACGACTT-3' (positions 1510-1492). The PCR product was directly sequenced on an ABI 377 DNA sequencer using a dRhodamine Dye Terminator Cycle Sequencing kit (Applied Biosystems).

The 16S rDNA sequence was aligned with reference sequences by using the CLUSTAL W program, version 1.5 (Thompson et al., 1994). A phylogenetic tree was constructed from the evolutionary distance matrix calculated by the neighbour-joining method (Saitou \& Nei, 1987). The neighbour-joining analysis was performed with the MEGA program (Kumar et al., 1993).

\section{RESULTS}

\section{TCE degradation by strain KP23}

Strain KP23 $3^{\mathrm{T}}$ was isolated from an aquifer sample collected at a TCE-polluted site using $2 \mathrm{mM}$ phenol as sole carbon source. This isolate showed TCE degradation activity. Its TCE transformation capacity $(T c)$, which is the maximum mass of TCE that can be transformed per unit mass of cells, was $54 \cdot 4 \mu \mathrm{g}$ (g dry 


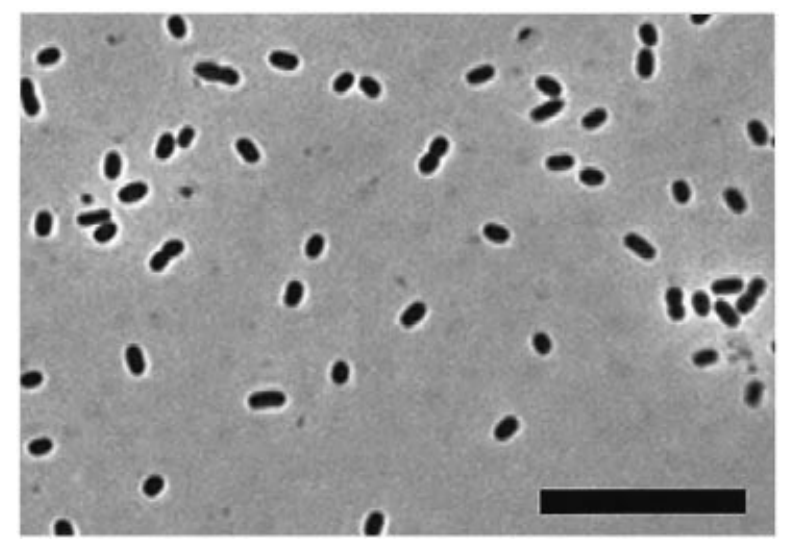

Fig. 1. Phase-contrast photomicrograph of strain $\mathrm{KP} 23^{\mathrm{T}}$ cells aerobically grown in PE medium at $37^{\circ} \mathrm{C}$. Bar, $10 \mu \mathrm{m}$.

cell $\mathrm{wt})^{-1}$. The pseudo-first-order degradation rate constant, $k_{1}$, was $12 \cdot 81 \mathrm{~g}^{-1} \mathrm{~h}^{-1}$.

Aromatic substrate utilization and induction of TCE degradation were investigated. The following 28 substrates were tested: phenol, benzene, fluorobenzene, $p$-cresol, toluene, chlorobenzene, nitrobenzene, $m$ chlorotoluene, $o$-nitrotoluene, $p$-nitrotoluene, $m$-nitrotoluene, $m$-dichlorobenzene, $o$-dichlorobenzene, $p$-dichlorobenzene, naphthalene, $m$-chlorophenol, $o$-chlorophenol, $p$-chlorophenol, $m$-cresol, $o$-cresol, 2-fluorophenol, 2,5-dichlorophenol, 2,4,6-trichlorophenol, $m$-nitrophenol, indigo, indene, indan and xylene. Of the substrates tested, phenol, benzene, fluorobenzene and $p$-cresol were utilized as sole carbon source, and only phenol induced TCE degradation.

\section{Morphology}

Colonies of strain $\mathrm{KP} 23^{\mathrm{T}}$ on PE medium plates were light yellow to grey. No diffusible pigment was produced. Under the microscope, the cells appeared as ovoids to short rods $1.2-1.5 \mu \mathrm{m}$ in length and $1.0 \mu \mathrm{m}$ in width (Fig. 1). Cells were non-motile. Spores were not observed. Gram-staining was negative. Electron microscopy demonstrated that the cells of strain KP $23^{\mathrm{T}}$ possessed a typical Gram-negative cell wall structure and no invaginations of intracytoplasmic membranes (Fig. 2).

\section{Physiological and biochemical characteristics}

Strain KP23 $3^{\mathrm{T}}$ grew between 15 and $42{ }^{\circ} \mathrm{C}$ with an optimum temperature of $37^{\circ} \mathrm{C}$, whilst no growth was detected at 10 or $45^{\circ} \mathrm{C}$ within 10 d incubation. The $\mathrm{pH}$ range for growth was between 6.0 and $7 \cdot 8$, with the optimum $\mathrm{pH}$ at $7 \cdot 2$. The doubling time was approximately $1 \mathrm{~h}$ under optimum growth conditions in liquid PE medium.

A comparison of carbon source oxidation of strain

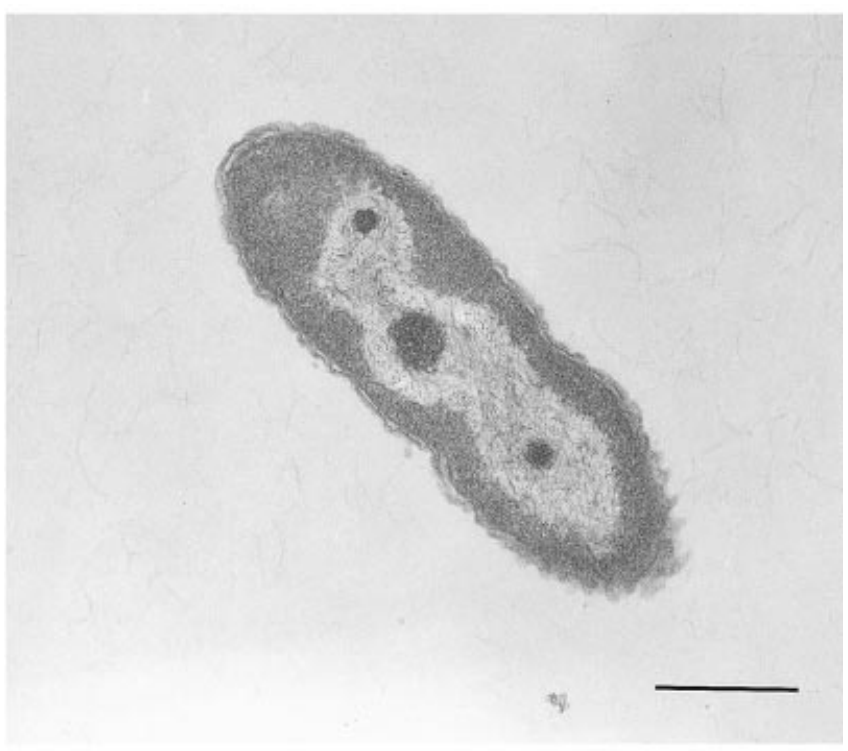

Fig. 2. Transmission electron micrograph of strain $\mathrm{KP} 23^{\top}$ cells showing the typical cell wall structure of Gram-negative bacteria. Bar, $0.5 \mu \mathrm{m}$.

$\mathrm{KP} 23^{\mathrm{T}}$ with type strains of 16 species in the genus Burkholderia is summarized in Table 1. Strain KP23 $3^{\mathrm{T}}$ was able to oxidize various sugars and sugar alcohols such as arabinose, galactose, glucose, fructose, fucose, lactulose, maltose, mannose, psicose, rhamnose, adonitol, arabitol, glycerol, inositol, mannitol, sorbitol and xylitol. In addition to the nutritional profile shown in Table 1, strain KP23 $3^{\mathrm{T}}$ was also able to oxidize the following substrates: acetate, citrate, formate, galacturonate, lactate, propionate, succinate, alanine, asparagine, aspartate, glutamate, glycine, histidine, leucine, phenylalanine, proline, serine, threonine, inosine and 2,3-butanediol. The following were not oxidized: cellobiose, lactose, melibiose, raffinose, sucrose, trehalose, malonate, dextrin, thymidine, uridine, glucose 1-phosphate and glucose 6-phosphate.

Neither starch hydrolysis nor gelatin liquefaction was observed, but Tween 80 and glycogen were hydrolysed. Catalase and oxidase were produced.

\section{Quinone and cellular fatty acid components}

The major respiratory quinone of strain $\mathrm{KP} 23^{\mathrm{T}}$ was ubiquinone (UQ)-8 ( $96 \cdot 1 \%$ of total quinones). Small amounts of UQ-7 (3.4\%) and UQ-9 (0.5\%) were also detected.

The main fatty acids in the cells of strain $\mathrm{KP} 23^{\mathrm{T}}$ were cyclopropanic acid $\left(\mathrm{C}_{19: 0} ; 25 \cdot 7 \%\right.$ of total fatty acid methyl esters), $\mathrm{C}_{16: 0}(22.6 \%)$ and cyclopropanic acid $\left(\mathrm{C}_{17: 0} ; 16.6 \%\right)$. Strain $\mathrm{KP} 23^{\mathrm{T}}$ also contained $\mathrm{C}_{14: 0}$ $(7.5 \%), \mathrm{C}_{18: 1}(7.5 \%), \mathrm{C}_{16: 1}(6.8 \%), 2-\mathrm{OH} \mathrm{C}_{16: 0}$ $(4 \cdot 5 \%), 3-\mathrm{OHC} \mathrm{C}_{16: 0}(3 \cdot 7 \%), \mathrm{C}_{13: 1}(3.3 \%), \mathrm{C}_{17: 1}(1 \cdot 8 \%)$ and a trace amount of $3-\mathrm{OH} \mathrm{C} \mathrm{C}_{14: 0}$. 
Table 1. Characteristics of carbon source oxidation of strain $\mathrm{KP} 23^{\top}$ as opposed to type strains of Burkholderia species

Strains: 1, strain KP23" ; 2, B. phenazinium; 3, B. glathei; 4, B. cepacia; 5, B. pyrrocinia; 6, B. vietnamiensis; 7, B. glumae; 8, B. plantarii; 9, B. gladioli; 10, B. caryophylli; 11, B. andropogonis; 12, B. plantarii (formerly B. vandii; Coenye et al., 1999); 13, B. gladioli (formerly $B$. cocovenenans; Coenye et al., 1999); 14, B. mallei; 15, B. pseudomallei; 16, B. graminis; and 17, B. caribensis. The results for type strains of Burkholderia are those of Viallard et al. (1998) and Achouak et al. (1999). +, Positive; -, negative. Galactose, gluconate, glucose, glycerol, inositol, mannitol and mannose were oxidized by all strains.

\begin{tabular}{|c|c|c|c|c|c|c|c|c|c|c|c|c|c|c|c|c|c|}
\hline \multirow[t]{2}{*}{ Oxidation of: } & \multicolumn{17}{|c|}{ Strains } \\
\hline & 1 & 2 & 3 & 4 & 5 & 6 & 7 & 8 & 9 & 10 & 11 & 12 & 13 & 14 & 15 & 16 & 17 \\
\hline Adonitol & + & + & + & + & + & - & + & - & + & + & + & - & - & - & - & + & + \\
\hline Arabinose & + & + & + & + & + & + & + & + & + & + & + & + & + & - & - & + & + \\
\hline Arabitol & + & + & + & + & + & + & + & + & + & + & + & + & + & - & + & + & + \\
\hline Cellobiose & - & - & - & + & + & + & - & - & - & - & - & + & - & - & - & + & - \\
\hline Fructose & + & + & + & + & + & + & + & + & + & + & + & + & + & - & + & + & + \\
\hline Fucose & + & + & + & + & + & + & + & + & + & + & - & + & + & - & + & + & + \\
\hline Lactose & - & - & + & - & - & - & - & - & - & - & + & - & - & - & - & + & + \\
\hline Maltose & + & - & - & - & - & - & - & - & - & - & - & - & - & - & - & - & + \\
\hline Melibiose & - & - & - & - & - & - & + & - & - & - & - & - & - & - & - & - & - \\
\hline Raffinose & - & - & - & - & - & + & + & - & - & + & - & - & - & - & - & + & - \\
\hline Rhamnose & + & + & + & - & - & - & - & + & - & + & - & - & - & - & - & + & + \\
\hline Sorbitol & + & + & + & + & + & + & + & + & + & + & + & + & + & - & + & + & + \\
\hline Sucrose & - & + & - & + & + & + & - & - & - & + & - & - & - & + & + & + & - \\
\hline Trehalose & - & - & - & + & + & + & + & + & + & + & - & + & + & + & - & + & + \\
\hline Xylitol & + & + & + & + & + & - & - & - & - & + & - & - & + & - & - & + & + \\
\hline
\end{tabular}

\section{Phylogenetic analysis based on 16S rRNA sequence}

A sequence (1461 nucleotides) of the 16S rRNA gene of strain KP $23^{\mathrm{T}}$ was determined. A phylogenetic tree was constructed by using the neighbour-joining method (Saitou \& Nei, 1987) (Fig. 3). The sequence of Neisseria gonorrhoeae, which belongs to the $\beta$-subclass of the Proteobacteria, was used to root the tree. Strain $\mathrm{KP} 23^{\mathrm{T}}$ was placed as a member of the genus Burkholderia. It was closely related to Burkholderia caribensis (sequence similarity 95.9\%), Burkholderia graminis $(94.9 \%)$ and Burkholderia phenazinium (94.9\%).

The $\mathrm{G}+\mathrm{C}$ content of the total DNA of strain KP23 was $64.8 \mathrm{~mol} \%$.

\section{DISCUSSION}

Strain KP23 $3^{\mathrm{T}}$, which showed TCE-degrading activity, was isolated from an aquifer polluted with TCE by enriching with phenol as sole carbon source. The TCE degrading activity was comparable with other known TCE-degraders. Of the substrates tested, only phenol induced TCE-degrading activity, suggesting that degradation is catalysed by phenol hydroxylase. Phylogenetic analysis based on the 16S rRNA gene sequence revealed that strain $\mathrm{KP} 23^{\mathrm{T}}$ is a member of the $\beta$ Proteobacteria and is distant from the other bacteria known as TCE degraders in this subclass, i.e. Burkholderia cepacia strain G4, Burkholderia sp. strain
KP24, Burkholderia sp. strain MBIC3837 and a few degraders belonging to the genus Ralstonia (Fig. 3).

The sequence analysis suggested that the new isolate belongs to the genus Burkholderia. Several phenotypic characteristics of the strain supported this assignment. The dominant respiratory quinone of the isolate was UQ-8, like other members of this genus (Urakami et al., 1994). FAME analysis of strain KP23 $3^{\mathrm{T}}$ showed the presence of 3-OH C16:0, which was a characteristic feature of the genus Burkholderia (Viallard et al., 1998). The main cellular fatty acids in the strain were similar to those of representative species in the genus Burkholderia (Yabuchi et al., 1992, 1995). Strain $\mathrm{KP} 23^{\mathrm{T}}$ was able to oxidize galactose, glucose, mannose, glycerol, inositol, mannitol and sorbitol. This oxidation profile resembles those of all species belonging to the genus Burkholderia. The total DNA $\mathrm{G}+\mathrm{C}$ content of the isolate $(64.8 \mathrm{~mol} \%)$ was also within the range of Burkholderia species (Yabuchi et al., 1992; Urakami et al., 1994).

However, the similarities of the 16S rRNA gene sequence of strain KP $23^{\mathrm{T}}$ with those of all Burkholderia species were less than $96 \%$. The sequence similarities to closely related species, $B$. caribensis, $B$. graminis and B. phenazinium, were $95.9,94.9$ and $94.9 \%$, respectively. Such low sequence similarities suggest that the isolate can be assigned to a novel species of the genus. Our phenotypic analysis of strain KP $23^{\mathrm{T}}$ also revealed 


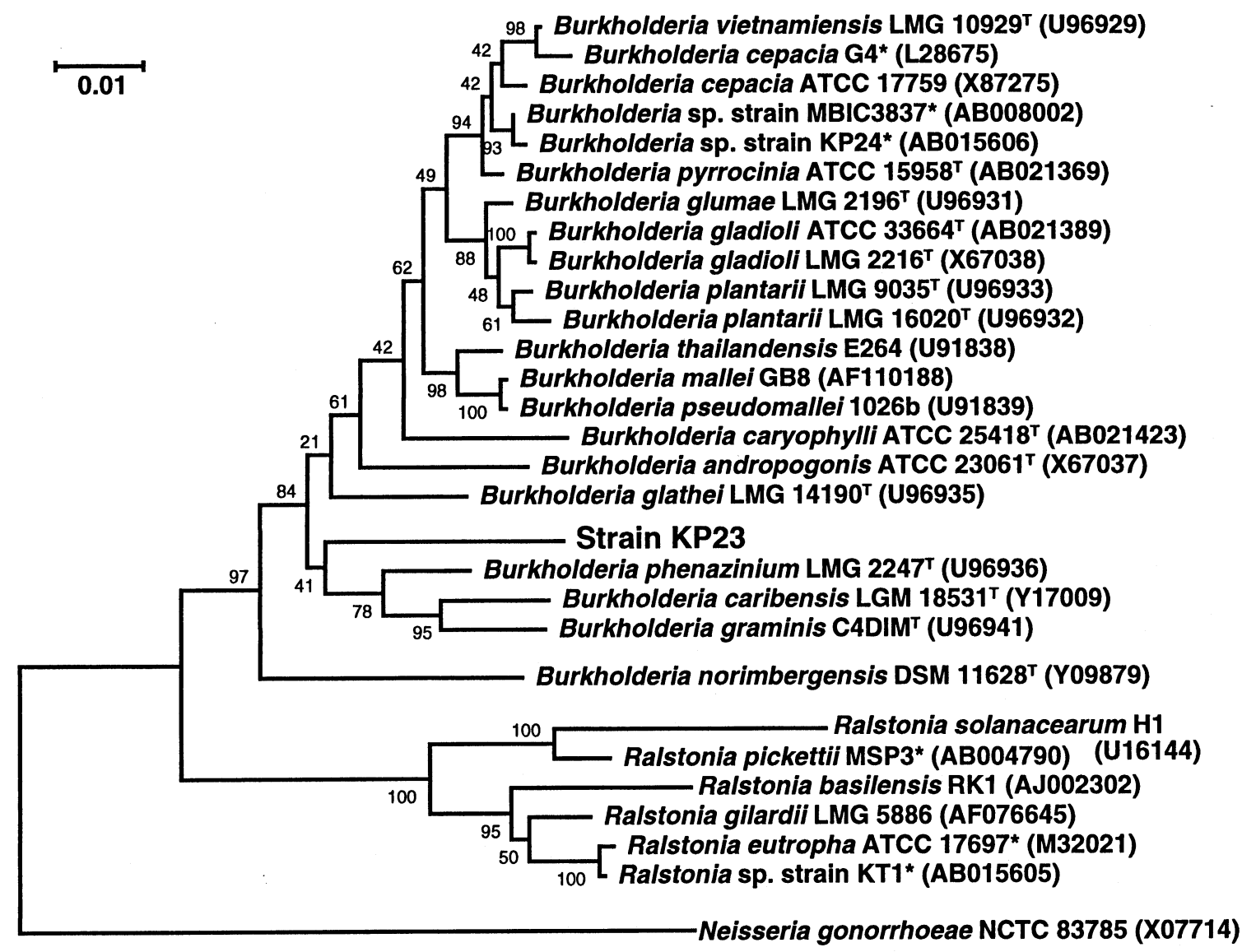

Fig. 3. Phylogenetic tree showing the relationship between strain $\mathrm{KP} 23^{\top}$ and related species in the $\beta$-subclass of the Proteobacteria based on 16S rDNA sequences. The bar represents 1 nucleotide substitution per 100 nucleotides. Bootstrap probabilities (Kumar et al., 1993) are indicated at the branch points. Asterisks indicate strains or species which are known to be TCE degraders. The GenBank accession number for each reference strain is shown in parentheses.

that there are several sufficient differences between the isolate and existing members of the genus Burkholderia to assign it to a new species: (1) cells of strain KP23 grown on PE medium are ovoids to short rods and morphologically different from known Burkholderia species, which are typical rod-shaped micro-organisms (Palleroni, 1984); (2) no motility is observed in strain KP23 ${ }^{\mathrm{T}}$ whilst all Burkholderia species (except Burkholderia mallei) are motile by means of one or several flagella; (3) strain $\mathrm{KP} 23^{\mathrm{T}}$ contains $\mathrm{C}_{13: 1}$ and $\mathrm{C}_{17: 1}$, which have not been detected in any other Burkholderia species; (4) the isolate grows optimally at $37^{\circ} \mathrm{C}$, whilst the optimum growth temperatures for almost all of the other strains belonging to the genus are in the range 28 to $30^{\circ} \mathrm{C}$.

Analysis of carbon source oxidation by the BIOLOG system revealed that the isolate was able to oxidize maltose. This is a remarkable nutritional feature of the isolate because all the other members of the genus Burkholderia, except for B. caribensis, lack the ability to oxidize this substrate. B. caribensis is one of the closest relatives based on 16S rRNA gene sequences. These two bacteria are, however, clearly distinguishable by their ability to oxidize lactose and trehalose: strain $\mathrm{KP} 23^{\mathrm{T}}$ does not oxidize these sugars but $B$. caribensis does.

On the basis of above phenotypic and phylogenetic analyses, strain KP $23^{\mathrm{T}}$ should be classified as a new species in the genus Burkholderia, and here we propose the name Burkholderia kururiensis sp. nov for the isolate.

\section{Description of Burkholderia kururiensis sp. nov.}

Burkholderia kururiensis (ku.ru.ri.en'sis. M.L. adj. kururiensis referring to Kururi, Chiba Prefecture, Japan, where the strain was isolated).

Cells are Gram-negative, non-motile, ovoids to short rods $(1.0 \mu \mathrm{m}$ in width and $1.2-1.5 \mu \mathrm{m}$ in length), and occur singly or in pairs. Growth occurs between 15 and $42{ }^{\circ} \mathrm{C}$ with the optimum at $37^{\circ} \mathrm{C}$. The $\mathrm{pH}$ range is 6.0-7.8. Optimum growth occurs at $\mathrm{pH} 7 \cdot 2$. The doubling time is approximately $1 \mathrm{~h}$ under optimum growth conditions. Oxidase and catalase are produced. No hydrolysis of starch and gelatin is observed, but glycogen and Tween 80 are hydrolysed. The following are oxidized: arabinose, fructose, fucose, galactose, glucose, lactulose, maltose, mannose, psicose, rham- 
nose, adonitol, arabitol, glycerol, inositol, mannitol, sorbitol, xylitol, $N$-acetylgalactosamine, acetate, citrate, formate, galacturonate, gluconate, lactate, propionate, alanine, asparagine, aspartate, glutamate, glycine, histidine, leucine, phenylalanine, proline, serine, threonine, inosine, 2,3-butanediol, benzene, $p$-cresol, fluorobenzene and phenol. The following are not oxidized: cellobiose, lactose, melibiose, raffinose, sucrose, trehalose, dextrin, malonate, uridine, thymidine, glucose 1-phosphate and glucose 6-phosphate. UQ-8 is the dominant respiratory quinone. Main cellular fatty acids are $\mathrm{C}_{16: 0}$, cyclopropanic acid $\mathrm{C}_{17: 0}$, cyclopropanic acid $\mathrm{C}_{19: 0}, \mathrm{C}_{16: 1}$ and $\mathrm{C}_{18: 1}$. $\mathrm{C}_{13: 1}$ and $\mathrm{C}_{17: 1}$ are also present. The $\mathrm{G}+\mathrm{C}$ content is $64 \cdot 8 \mathrm{~mol} \%$. The organism was isolated from an aquifer polluted with TCE in Kururi, Chiba Prefecture, Japan and shows degradation activity for this contaminant when cells are grown in the presence of phenol. The type strain is $\mathrm{KP} 23^{\mathrm{T}}\left(=\mathrm{JCM} 10599^{\mathrm{T}}\right)$.

\section{ACKNOWLEDGEMENTS}

We thank Xian-Ying Meng for the electron microscopy. This study was conducted as one of the research and development activities of the bioremediation project, which is handled by the Research Institute of Innovative Technology for the Earth (RITE), Japan, and funded by the Ministry of International Trade and Industry (MITI) through the New Energy and Industrial Technology Development Organization (NEDO).

\section{REFERENCES}

Achouak, W., Christen, R., Barakat, M., Martel, M.-H. \& Heulin, T. (1999). Burkholderia caribensis sp. nov., an exopolysaccharideproducing bacterium isolated from vertisol microaggregates in Martinique. Int J Syst Bacteriol 49, 787-794.

Byrne, A. M., Kukor, J. J. \& Olsen, R. H. (1995). Sequence analysis of the gene cluster encoding toluene-3-monooxygenase from Pseudomonas pickettii PKO1. Gene 154, 65-70.

Cardy, D. L., Laidler, V., Salmond, G. P. C. \& Murrell, J. C. (1991). Molecular analysis of the methane monooxygenase (MMO) gene cluster of Methylosinus trichosporium OB3b. Mol Microbiol 5, 335-342.

Coenye, T., Holmes, B., Kersters, K., Govan, J. R. W. \& Vandamme, P. (1999). Burkholderia cocovenenans (van Damme et al. 1960) Gillis et al. 1995 and Burkholderia vandii Urakami et al. 1994 are junior synonyms of Burkholderia gladioli (Severini 1913) Yabuuchi et al. 1993 and Burkholderia plantarii (Azegami et al. 1987) Urakami et al. 1994, respectively. Int J Syst Bacteriol 49, $37-42$.

Dabrock, B., Riedel, J., Bertram, J. \& Gottschalk, G. (1992). Isopropylbenzene (cumene) - a new substrate for the isolation of trichloroethylene-degrading bacteria. Arch Microbiol 158, 9-13.

Folsom, B. P., Chapman, P. J. \& Pritchard, P. H. (1990). Phenol and trichloroethylene degradation by Pseudomonas cepacia G4: kinetics and interactions between substrates. Appl Environ Microbiol 56, 1279-1285.

Hanada, S., Hiraishi, A., Shimada, K. \& Matsuura, K. (1995). Chloroflexus aggregans sp. nov., a filamentous phototrophic bacterium which forms dense cell aggregates by active gliding movement. Int J Syst Bacteriol 45, 676-681.
Hanada, S., Shigematsu, T., Shibuya, K., Eguchi, M., Hasagawa, T., Suda, F., Kamagata, Y., Kanagawa, T. \& Kurane, R. (1998). Phylogenetic analysis of trichloroethylene-degrading bacteria newly isolated from soil polluted with this contaminant. $J$ Ferment Bioeng 86, 539-544.

Harker, A. R. \& Kim, Y. (1990). Trichloroethylene degradation by two independent aromatic-degrading pathways in Alcaligenes eutrophus JMP134. Appl Environ Microbiol 4, 1179-1181.

Herrmann, H., Muller, C., Schmidt, I., Mahnke, J., Petruschka, L. \& Hahnke, K. (1995). Localization and organization of phenol degradation genes of Pseudomonas putida strain H. Mol Gen Genet 247, 240-246.

Hiraishi, A. (1992). Direct automated sequencing of 16S rDNA amplified by polymerase chain reaction from bacterial cultures without DNA purification. Lett Appl Microbiol 15, 210-213.

Hiraishi, A., Shin, Y. K., Ueda, Y. \& Sugiyama, J. (1994). Automated sequencing of PCR-amplified 16S rDNA on 'Hydrolink' gels. J Microbiol Methods 19, 145-154.

Kamagata, Y. \& Mikami, E. (1991). Isolation and characterization of a novel thermophilic Methanosaeta strain. Int J Syst Bacteriol 41, 191-196.

Kim, Y. J., Ayoubi, P. \& Harker, A. R. (1996). Constitutive expression of the cloned phenol hydroxylase gene(s) from Alcaligenes eutrophus JMP134 and concomitant trichloroethylene oxidation. Appl Environ Microbiol 62, 3227-3233.

Kumar, S., Tamura, K. \& Nei, M. (1993). MEGA: molecular evolutionary genetics analysis, version 1.0. The Pennsylvania State University, University Park, PA, USA.

Kushida, H. (1980). An improved embedding method using ERL 4206 and Quetol 653. J Electron Microsc 29, 193-194.

Little, C. D., Palumbo, A. V., Herbes, S. E., Lidstorm, M. E., Tyndall, R. L. \& Gilmer, P. J. (1988). Trichloroethylene biodegradation by a methane-oxidizing bacterium. Appl Environ Microbiol 54, 951-956.

McDonald, I. R., Uchiyama, H., Kambe, S., Yagi, O. \& Murrell, J. C. (1997). The soluble methane monooxygenase gene cluster of the trichloroethylene-degrading methanotroph Methyocystis sp. strain M. Appl Environ Microbiol 63, 1898-1904.

Magee, C. M., Rodeheaver, G. \& Edgerton, R. F. (1975). A more reliable gram staining technique for diagnosis of surgical infections Am J Surg 130, 341-346.

Nelson, M. J. K., Montgomery, S. O., Mahaffey, W. R. \& Pritchard, P. H. (1987). Biodegradation of trichloroethylene and the involvement of an aromatic biodegradative pathway. Appl Environ Microbiol 53, 949-954.

Nelson, M. J. K., Montgomery, S. O. \& Pritchard, P. H. (1988). Trichloroethylene metabolism by microorganisms that degrade aromatic compounds. Appl Environ Microbiol 54, 604-606.

Nordlund, I., Powlowski, J. \& Shingler, V. (1990). Complete nucleotide sequence and polypeptide analysis of multicomponent hydroxylase from Pseudomonas sp. strain CF600. J Bacteriol 172, 6826-6833.

Palleroni, N. J. (1984). Genus I. Pseudomonas Migula 1894. In Bergey's Manual of Systematic Bacteriology, vol. 1, pp. 141-199. Edited by N. R. Krieg \& J. G. Holt. Baltimore: Williams \& Wilkins.

Saito, H. \& Miura, K. (1963). Preparation of transforming deoxyribonucleic acid by phenol treatment. Biochim Biophys Acta 72, 619-629.

Saitou, N. \& Nei, M. (1987). The neighbor-joining method: a new method for reconstructing phylogenetic trees. Mol Biol Evol 4, 406-425. 
Sasser, M. \& Wichman, M. D. (1991). Manual of Clinical Microbiology, 5th edn, pp. 111-118. Edited by A. Balows, Jr, W. J. Hausler, K. Herrmann, H. Isenberg \& H. J. Shadomy. Washington, DC: American Society for Microbiology.

Shields, M. S., Montgomery, S. O., Chapman, P. J., Cuskey, S. M. \& Pritchard, P. H. (1989). Novel pathway of toluene catabolism in the trichloroethylene-degrading bacterium G4. Appl Environ Microbiol 55, 1624-1629.

Smibert, R. M. \& Krieg, N. R. (1994). Phenotypic characterization. In Methods for General and Molecular Bacteriology. Edited by P. Gerhardt, R. G. E. Murray, W. A. Wood \& N. R. Krieg. Washington, DC: American Society for Microbiology.

Speitel, G. E., Jr, Thompson, R. C. \& Weissman, D. (1993). Biodegradation kinetics of Methylosinus trichosporium OB3b at low concentrations of chloroform in the presence and absence of enzyme competition by methane. Water Res 27, 15-24.

Stainthorpe, A. C., Lees, V., Salmond, G. P. C., Dalton, H. \& Murrell, J. C. (1990). The methane monooxygenase gene cluster of Methylococcus capsulatus (Bath). Gene 91, 27-34.

Tamaoka, J., Katayama-Fujimura, Y. \& Kuraishi, H. (1983). Analysis of bacterial menaquinone mixtures by high performance liquid chromatography. J Appl Bacteriol 54, 31-36.

Thompson, J. D., Higgins, D. G. \& Gibson, T. J. (1994). CLUSTAL $\mathrm{W}$ : improving the sensitivity of progressive multiple sequence alignment through sequence weighting, position-specific gap penalties and weight matrix choice. Nucleic Acids Res 22, 4673-4680.

Tsein, H. C., Brusseau, G. A., Hanson, R. S. \& Wackett, L. P. (1989). Biodegradation of trichloroethylene by Methylosinus trichosporium OB3b. Appl Environ Microbiol 55, 3155-3161.

Urakami, T., Ito-Yoshida, C., Araki, H., Kijima, T., Suzuki, K.-I. \& Komagata, K. (1994). Transfer of Pseudomonas plantarii and Pseudomonas glumae to Burkholderia as Burkholderia spp. and description of Burkholderia vandii sp. nov. Int J Syst Bacteriol 44, 235-245.

Viallard, V., Poirier, I., Cournoyer, B., Haurat, J., Wiebkin, S., Ophel-Keller, K. \& Balandreau, J. (1998). Burkholderia graminis sp. nov., a rhizospheric Burkholderia species, and reassessment of [Pseudomonas] phenazinium, [Pseudomonas] pyrrocinia and [Pseudomonas] glathei as Burkholderia. Int J Syst Bacteriol 48, 549-563.

Wackett, L. P. \& Householder, S. R. (1989). Toxicity of trichloroethylene to Pseudomonas putida F1 is mediated by toluene dioxygenase. Appl Environ Microbiol 55, 2723-2725.

Wackett, L. P., Brusseau, G. A., Householder, S. R. \& Hanson, R. S. (1989). A survey of microbial oxygenases: trichloroethylene degradation by propane-oxidizing bacteria. Appl Environ Microbiol 55, 2960-2964.

Welch, D. E. (1991). Applications of cellular fatty acid analysis. Clin Microbiol Rev 4, 422-438.

Yabuuchi, E., Kosako, Y., Oyaizu, H., Yano, I., Hotta, H., Hashimoto, Y., Ezaki, T. \& Arakawa, M. (1992). Proposal of Burkholderia gen. nov. and transfer of seven species of the genus Pseudomonas homology group II to the new genus, with the type species Burkholderia cepacia (Palleroni and Holmes 1981) comb. nov. Microbiol Immunol 36, 1251-1275.

Yabuuchi, E., Kosako, Y., Yano, I., Hotta, H. \& Nishiuchi, Y. (1995). Transfer of two Burkholderia and an Alcaligenes species to Ralstonia gen. nov.: proposal of Ralstonia pickettii (Ralston, Palleroni and Doudoroff 1973) comb. nov., Ralstonia solanacearum (Smith 1896) comb. nov. and Ralstonia eutropha (Davis 1969) comb. Nov. Microbiol Immunol 39, 897-904.

Yen, K.-M., Karl, M. R., Blatt, L. M., Simon, M. J., Winter, R. B., Fausset, P. R., Lu, H. S., Harcourt, A. A. \& Chen, K. K. (1991). Cloning and characterization of a Pseudomonas mendocina KR gene cluster encoding toluene-4-monooxygenase. J Bacteriol 173, 5315-5327. 